\title{
SOCIEDADE CIVIL, REPRESENTAÇÃO E A DUPLA FACE DA ACCOUNTABILITY: cidade do México e São Paulo
}

\author{
Adrian Gurza Lavalle* \\ Graziela Castello*
}

\section{INTRODUÇÃO}

Quando o controle social sobre o poder público e suas burocracias é exercido por atores coletivos organizados e não por cidadãos em sua condição inerentemente individualizada ("cidadãos avulsos"), necessariamente ocorrem modalidades de representação política cujas lógicas de funcionamento, constituição e legitimidade ainda não foram investigadas o suficiente, embora venham despertando cada vez mais atenção, como demonstra o surgimento e o crescimento de agendas de

* Doutor em Ciência Política pela USP. Professor do Departamento de Ciência Política USP e pesquisador do Centro Brasileiro de Análise e Planejamento - CEBRAP Rua Morgado de Mateus 615 Vila Mariana São Paulo/SP - 04015902.layda@usp.br

* * Mestranda de Ciências Sociais na Universidade Estadual de Campinas - UNICAMP e pesquisadora do Centro Brasileiro de Análise e Planejamento - CEBRAP. grazielacastello@yahoo.com.br

Agradecemos os comentários criteriosos de Ernesto Isunza, Cícero Araújo, Monika Dowbor e Roberta Soromenho a versões preliminares deste texto, que resume e adequa para o debate local nosso capitulo escrito para o livro de Ernesto Isunza Vera e Adrian Gurza Lavalle. Veredas de innovación democrática. Teoría y práctica de la representación, la participación y el control ciudadanos en América Latina. Ciudad de México, Editorial Porrúa. (Trabalho não publicado). investigação sobre a accountability interna nas organizações da sociedade civil e das práticas de representação política que elas exercem. ${ }^{1}$ Essas novas práticas de representação política se situam, atualmente, na fronteira dainovação democrática, mas suas implicações para a democracia dependem não apenas de faculdades e capacidades de controle e incidência sobre o poder público e suas estruturas administrativas, mas também das relações que os novos atores da representação mantêm com os eventuais beneficiários, em nome dos quais falam e exercem essa representação. Portanto, o velho dilema do controle dos controladores torna-se iniludível, revelando que a accountability societal exige uma análise que leve em consideração as duas faces do controle. Este artigo aborda essa questão do ponto de vista da teoria democrática, a partir de uma análise comparativa entre práticas de representação exercidas por organizações ci-

${ }^{1}$ Vide, por exemplo, apenas para citar a literatura internacional, as publicações de Chalmers e Vilas (1997), particularmente o capítulo do próprio Chalmers, Martin e Piester (1997). Mais recentemente, vide, também, os trabalhos de Friedman e Hochstetler (2002), Urbinati (2000), Urbinati e Warren (2007), Castiglione e Warren (2005), Törnquist, Webster e Stokke (Trabalho não publicado). 
vis em duas metrópoles latino-americanas.

A accountability societal, quer dizer, a que é acionada por parte de atores coletivos em funções de representação que são desempenhadas de jure ou de facto perante o poder público e suas instâncias administrativas, tem grande relevância para a teoria democrática e para o futuro das inovações democráticas participativas ensaiadas ao longo dos últimos anos em latitudes diversas. A reestruturação profunda das economias, as transformações do estado e a mudança de paradigmas burocrático-administrativos - expressos em idéias como "governança”, "Estado-rede”, "pluralização do Estado" e "heterogeneidade do Estado", entre outras - multiplicaram as interfaces de contato institucionalizado entre o poder público e interesses sociais organizados e representados, nas quais diferentes modalidades de accountability societal passam a ser possíveis. ${ }^{2}$ Isso acontece para além das instâncias tradicionais de representação política e das estratégias de concertação, em que grandes corporações oriundas do mundo do trabalho ocupam posições privilegiadas.

Na verdade, não se trata, atualmente, de processos de macrorrepresentação social incumbidos de produzir consensos sobre a definição dos objetivos gerais do governo, bem como sobre a distribuição dos benefícios e a imposição das perdas, associadas a tais objetivos - processos que são próprios da representação eleitoral e funcional (gremial ou sindical). Antes, as transformações em curso estão associadas à pluralização da representação, isto é, à proliferação de experiências de representação em níveis micro e médio, destinadas a incidir no desempenho das burocracias e dos serviços públicos, com vistas a aperfeiçoá-los (Gurza Lavalle; Houtzager; Castello, 2006a). Mais precisamente, é possível identificar um impulso favorável a inovações institucionais participativas e, como conseqüência involuntária, um deslocamento progressivo em di-

${ }^{2}$ A multiplicação de idéias com um registro semelhante manifesta o espírito do tempo pós-fordista e pósdesenvolvimentista. Distintos autores desenvolveram as idéias listadas no texto. Vide, por exemplo, os trabalhos de Ansell (2000), Dagnino, Olvera e Panfichi (2006), Marques (2006) e Chandhoke (2003). reção à pluralização dos atores da representação política e das funções tradicionais da própria representação: outros atores coletivos distintos de partidos ou sindicatos, exercendo funções que não são de legislação ou controle da cabeça do executivo nem de negociação com relação à distribuição social da riqueza na forma de lucros ou beneficio do trabalho, e sim de fiscalização e co-gestão de políticas dentro do próprio poder executivo. ${ }^{3}$

Entretanto, esse novo panorama apresenta a questão da dupla face da accountability societal. ${ }^{4} \mathrm{~A}$ accountability supõe a obrigação de prestar contas, implica a possibilidade de sanção e compõe um subconjunto do repertório de práticas de controle interinstitucional e social. No caso do controle social, sempre que se fala em nome de alguém, ou o sujeito da fala comparece como membro de uma entidade ou grupo nas inovações institucionais participativas e nos espaços de negociação, a lógica da auto-apresentação como explicitação de interesses e opiniões individuais, própria da participação, é substituída pela lógica da representação. Sendo assim, cabe perguntar pela qualidade ou representatividade dessa representação, pelos mecanismos que a tornam legítima não apenas em relação ao poder público, mas também em relação aos representados ou beneficiários em nome dos quais se atua e se negocia. Nesse sentido, modalidades de controle societal, nas quais se encontram

\footnotetext{
Sem entrar em questões de mérito ou eficácia, há vários exemplos de inovações institucionais que apontam para a pluralização da representação política e da accountability societal: leis de direito à informação e a transparência orçamentos participativos, conselhos gestores de políticas, comitês participativos em diversas instâncias da administração pública, a multiplicação da presença institucional de ombdusmans, audiências públicas, observatórios cidadãos, legislações sobre o terceiro setor. Para países do hemisfério norte, vide a coleção de trabalhos no volume editado por Cain, Dalton e Scarrow (2003); para o hemisfério sul, vide os volumes editados por Cornwall e Coelho (2007) e por Santos (2002); para América Latina, vide os trabalhos do volume editado por Isunza e Gurza, no prelo; para o caso mexicano, consultem-se os volumes coordenados por Isunza e Olvera (2006a); Fox, Haight, Hofbauer e Sánchez (2007). No Brasil, a literatura sobre orçamento participativo e conselhos gestores é farta.

Aspectos da questão da dupla face da accountability societal foram explorados mediante as idéias de "representação presuntiva", "representatividade", "representação virtual" e "paradoxos da representação da sociedade civil” em Gurza Lavalle, Houtzager e Castello, 2006a; 2006b; da mesma forma, em Gurza Lavalle e Isunza, Houtzager e Gurza Lavalle (Trabalhos não publicado).
} 
organizações civis que representam interesses, espaços de interlocução institucionalizados e faculdades decisórias com caráter vinculante, revelamse altamente exigentes em um duplo sentido. Por um lado, satisfazem as expectativas mais elevadas do ideário da democracia participativa, cujos expoentes acusam freqüentemente as insuficiências e distorções que nesses espaços minam a "participação" e obstaculizam tentativas autênticas de "partilhar o poder" - segundo a influente formulação de Dagnino (2002). Mas, por outro lado, impõem exigências a respeito da representatividade, responsividade ${ }^{5}$ e sanção dos que falam em nome dos demais, suscitando a velha questão do controle dos controladores.

Sem dúvida, seria possível, ainda que pouco produtivo, cancelar analiticamente o registro da representação, partindo-se do princípio de que se trata de representação sem autorização nem constituency claramente definidas e, portanto, de controladores aparentemente emancipados de qualquer controle social. Nessas condições, a representação seria, por definição, impossível ou nãodemocrática. ${ }^{6}$ Esperar que organizações civis satisfaçam os requisitos da representação como se fossem partidos ou sindicatos indica profunda insensibilidade com relação à pluralidade e ao caráter de novidade do fenômeno em questão. Não existem modelos históricos nem analíticos consagrados de representação e accountability de organizações civis e, por isso, parece pertinente buscar uma alternativa que permita avançar na

5 "Responsivo" é que tem inclinação a responder. A "responsividade política” se refere, normalmente, à sensibilidade do governo e dos representantes diante das inquietudes e demandas dos governados e dos representados, expressada mediante algum tipo de resposta. Dessa forma, a "responsividade" guarda parentesco semântico estreito com "responsabilidade", mas, nesse caso, ser responsável pressupõe responder pelo cuidado de algo ou de alguma coisa e estar sujeito a penalização. A diferença entre responsabilidade e responsividade é crucial para as teorias da representação, pois, diferentemente da representação de interesses no direito civil, na representação eleitoral o representante não pode ser responsabilizado juridicamente por descumprir o "contrato" ou acordo com o representado. As eleições são um mecanismo de sanção e autorização, mas funcionam promovendo a responsividade do representante (Vide Sartori, 1962; Galvão 1971; Campilongo 1988; Gurza Lavalle; Houtzager; Castello 2006a).

${ }^{6}$ Vide, por exemplo, Przeworski, 2002 e Chandoki, 2003. problematização e na compreensão da pluralização da representação, mais do que cancelar as perguntas no nascedouro.

Na verdade, é possível seguir outro caminho, como mostram os recentes redirecionamentos da literatura, aos quais subjaz a convicção de que os processos de pluralização da representação em curso exigem a construção de novas estratégias conceituais. A crescente difusão da semântica do controle nos campos da teoria democrática, da sociedade civil e do terceiro setor constitui a adoção de uma estratégia conceitual que permite situar a problemática da legitimidade das práticas de representação exercidas pelas organizações civis em um terreno diferente do da autorização, com freqüência precária ou simplesmente inexistente. ${ }^{7}$ Por outras palavras, perante a impossibilidade de se equacionar satisfatoriamente o quesito da autorização, a dimensão da accountability vem sendo resgatada como alternativa para explorar teórica e empiricamente a eventual legitimidade das novas práticas de representação por organizações civis (Peruzzotti, 2007; Alnoor; Weisband, 2007; Urbinati; Warren, 2007; Castiglione; Warren, 2006). A operação de deslocar a atenção da autorização para centrá-la na accountability abre passo para se pensar na legitimidade em função, não de um ato inicial de consentimento, mas dos processos mediante os quais as organizações civis internalizam, definem e depuram as prioridades e propósitos da representação por elas exercida.

Este artigo dá continuidade a uma linha de investigação e reflexão teórica sobre os processos de pluralização da representação. Principalmente sobre as funções de representação política exercidas por organizações civis, os processos de reconfiguração da representação, a relação de ambos com as inovações democráticas participativas, assim como a conexão entre essas modalidades de representação e os eventuais mecanismos de accountability a elas associados, que foram tratados em outros artigos. ${ }^{8}$ Aqui abordamos, no plano

\footnotetext{
${ }^{7}$ Para um balanço desse deslocamento, vide Gurza Lavalle;
} Isunza (Trabalho não publicado). 
empírico, a dupla face da accountability societal, utilizando os resultados de dois surveys realizados na Cidade do México e em São Paulo. Foram entrevistadas mais de 400 organizações civis (líderes ou membros da direção) e os critérios de escolha privilegiaram as organizações ativas nos segmentos mais pobres da população, o que torna os resultados aqui expostos particularmente oportunos para as agendas de aprofundamento da democracia. ${ }^{9}$ Cabe mencionar que este artigo parte de uma análise realizada para o caso de São Paulo (Gurza Lavalle; Houtzager; Castello 2006b), mas a reformula à luz do debate sobre a dupla face da accountability societal e dos resultados da Cidade do México, contemplando as variações apresentadas pelos diferentes tipos de organizações civis nos dois contextos - resultados que são totalmente inéditos. Sempre que for pertinente, e com vistas a evitar repetições, serão indicadas ao leitor as formulações já publicadas, reservando-se estas páginas para formulações mais depuradas e de caráter comparativo.

Com o propósito de problematizar empiricamente a dupla face da accountability societal, serão examinadas as noções de representação existentes no seio das organizações civis da Cidade do México e de São Paulo. Mais precisamente, o artigo centra a atenção nas noções sedimentadas no discurso público das organizações que, nos dois contextos urbanos, assumem a representação de seus públicos ou dos grupos da população que defendem (doravante, "beneficiários"). Ao adotar como objeto de análise as noções de representação presentes nos universos de organizações civis estudados, nãoé possível afirmar que as organizações em questão exerçam práticas de representação em instâncias institucionalizadas e investidas de faculdades

${ }^{8}$ Vide, em Gurza Lavalle, Acharya e Houtzager, 2005; Gurza Lavalle, Houtzager e Castello, 2006a e 2006b; Gurza Lavalle e Isunza (Trabalho não publicado).

${ }^{9}$ Os resultados empíricos apresentados nestas páginas formam parte do projeto de investigação "Rights, Representatiom and the Poor: Comparing Large Developing Country Democracies. Brazil, India and Mexico“. Informações e publicações do projeto estão disponíveis para download em www.ids.ac.uk/gdr/cfs/ research/Collective\%20Ators.html. As publicações também podem ser acessadas na biblioteca virtual do Centro Brasileiro de Análise e Planejamento (CEBRAP): www.cebrap.org.br decisórias vinculantes. Ainda assim, os resultados são ricos do ponto de vista empírico e suficientemente esclarecedores acerca de possíveis respostas à questão da dupla face da accountability societal e de como elas estão sendo construídas na prática pelos novos atores da representação. Em todo o caso, as noções foram controladas pelo exercício efetivo de práticas de representação perante o poder público, algumas das quais acontecem em espaços institucionalizados, e se mostraram nitidamente consistentes (Gurza Lavalle; Houtzager; Castello, 2005).

Os resultados do estudo oferecem um panorama mais rico e diversificado do que fariam supor as posições apriorísticas de defesa ou condenação do papel da sociedade civil nas democracias. Ás vezes, existem expedientes de autorização que medeiam a relação de representação entre organizações civis e beneficiários, mas, na maior parte dos casos, trata-se de práticas de representação presuntiva, ou seja, unilaterais por parte daqueles que as exercem e não autorizadas pelos beneficiários em nome dos quais são exercidas. A representação presuntiva, própria de uma parte do repertório de atividades levadas a cabo pelas organizações civis - por exemplo, aquelas compreendidas na rubrica advocacy, para mencionar só um conjunto óbvio de atividades - pareceria incompatível com a idéia de accountability, pois essa pressupõe a definição clara do agente de controle com capacidades de sanção e diante do qual se prestam contas, no caso, os beneficiários. Não obstante, a opção analítica de trabalhar com noções de representação, em sua maior parte presuntivas, mostrou-se pertinente pelo fato de ajudar a evidenciar os custos cognitivos de posturas que formulam veredictos acerca da legitimidade ou ilegitimidade da chamada sociedade civil in toto. Curiosamente, às vezes, defensores e detratores da sociedade civil coincidem em tomar como premissa a unicidade do universo das organizações civis.

Muito embora dois terços ou mais das organizações civis examinadas nas duas cidades presumam a representação de seus beneficiários, fazem-no enfrentando de maneira distinta as duas faces da accountability societal e lançam mão de justificativas 
diferentes quanto à sua legitimidade. Um exame minucioso das noções de representação revelou a presença de seis tipos consistentes de justificativa: eleitoral, de filiação, de identidade, de proximidade, de serviços e de intermediação. Alguns desses tipos contam com mecanismos internos de controle social, mas outros acusam lógicas incompatíveis com exigências democráticas mínimas. Mais além, parte das justificativas reside em mecanismos de controle social plenamente consagrados e de uso corrente nas instituições democráticas. Também se observa a concentração de certos argumentos em determinados tipos de organizações civis. Assim, se, por um lado, a variação põe em cheque respostas apriorísticas únicas, animadas por concepções positivas ou negativas da sociedade civil, por outro, os padrões encontrados sugerem alternativas de teorização atentas aos efeitos das características funcionais das organizações civis sobre as práticas de intermediação política que exercem.

Além dos parágrafos desta introdução, o artigo está dividido em quatro seções: inicialmente se expõe a operacionalização dos conceitos que guiaram a investigação, assim como a origem e as principais características dos dados utilizados; na seção seguinte, apresentam-se os resultados da investigação sobre a elaboração discursiva associada às práticas de representação exercidas pelas organizações civis na Cidade do México e em São Paulo e, mais especificamente, de suas implicações para a inovação e o aprofundamento democráticos do ponto de vista da dupla face da accountability societal; na quinta e última seção, são exploradas as conseqüências mais gerais dos resultados apresentados, as semelhanças suscetíveis de maiores aprofundamentos analíticos e também apontam-se, de forma muito breve, as variações significativas entre contextos.

\section{ACCOUNTABILITYCOMO ESTRATÉGIADE INVESTIGAÇÃO}

A idéia de "accountability" oferece claras distinções analíticas e orientações para a pesquisa empírica, que permitem captar simultaneamente as práticas de representação por organizações civis em sua extraordinária diversidade, sem as condenar em conjunto, a priori, por seus déficits de legitimidade ou representatividade, mas sem deixar de julgá-las ex post, conforme os parâmetros normativos comumente aceitos na teoria democrática. Nesse sentido, a accountability opera simultaneamente como núcleo analítico com implicações relevantes para a teoria democrática e como estratégia de investigação. Como núcleo analítico, introduz exigências flexíveis, porém incontornáveis do ponto de vista da representação democrática, quanto à relação entre representante e representado: a prática do primeiro deve ser informada, em alguma medida e mediante algum mecanismo, pela avaliação do segundo. Assim, optar por uma estratégia analítica que permite ampliar o horizonte das práticas de representação, esquivando os impasses do requisito da autorização, não equivale a se furtar do momento da avaliação. Também é possível disputar os parâmetros da própria teoria democrática (vide, por exemplo, Young, 2002), mas essa opção não é menos controversa, exige de investimento de fôlego no plano da teoria política normativa e escapa dos limites deste artigo.

Como estratégia de investigação, a idéia de accountability sugere a utilidade de documentar diferentes modalidades de responsividade das organizações civis e de examiná-las em busca dos eventuais mecanismos internos de controle e sanção que as animam. Sem dúvida, também ressalta a importância de examinar cuidadosamente as modalidades de controle que essas organizações exercem sobre o poder público e suas instâncias administrativas. Essa última face da accountability societal tem recebido mais atenção e, com alguma freqüência, foi tratada sob uma tônica de denúncia ou defraudação das expectativas associadas ao ideário participativo. ${ }^{10}$ Nestas páginas, as duas faces serão contempladas na reconstrução dos resultados, mas apenas a primeira será sistematica-

${ }^{10}$ Um balanço inicial da literatura sobre participação nas inovações institucionais brasileiras, onde se mostra a tônica de denúncia e o sentimento de defraudação, pode ser consultado em Tatagiba, 2002; vide, também, Cornwall e Coelho, 2007b, Fung e Wright, 2003 e Heller, 2002. 
mente examinada com o propósito de extrair analiticamente suas conseqüências mais gerais.

Frente à ausência de constituencies pré-definidas e de procedimentos claros que permitissem identificar a relação entre representantes e representados, indagando a representatividade das ações dos primeiros, decidiu-se levar a sério e analisar com cuidado o discurso das organizações civis acerca de sua qualidade de representantes. Essas organizações podem rejeitar ou assumir unilateralmente ou de modo presuntivo o papel de representantes de seus beneficiários, mas, uma vez escolhida a segunda opção, torna-se imperioso invocar justificações para sustentar publicamente a índole genuína das relações de representação correspondentes (Gurza Lavalle; Houtzager; Castello, 2006b). Ao enfocar a representação presuntiva, esta análise se desenvolve integralmente no plano da elaboração discursiva dos atores analisados; não obstante, está longe de ser arbitrária e apresenta resultados que apontam a padrões claros.

Segundo sugerem os resultados, as justificativas inerentes à representação presuntiva tendem à decantação como discurso público plausível à medida que esses atores exercem mais funções de representação e enfrentam questionamentos acerca de sua representatividade. Assim, os motivos invocados atualizam a questão da representatividade e põem o ator em posição de explicitar (invocar) eventuais mecanismos internos de accountability como parte de sua justificação. Em realidade, em algumas ocasióes, segundo se verá, as justificativas contemplam de modo explícito ou implícito mecanismos internos de accountability, mas, em outras, as noções de representação sustentadas pelas organizações civis são claramente incompatíveis com as exigências democráticas.

Os trabalhos de campo foram realizados, respectivamente, no município de São Paulo, durante oito meses de 2002, e na Cidade do México (Distrito Federal) durante seis meses do ano seguinte. Há registro de 229 organizações localizadas em São Paulo e 196 na Cidade do México. Para conformar a amostra, as organizações foram escolhidas utilizando-se a técnica "bola de neve", cujas vantagens e limitações são conhecidas (Atkinsom; Flint, s.d; Goodman, 1961; Sudmam; Kalton, 1986).Questionários, critérios de administração dos fluxos de entrevistas gerados pela bola de neve e testes realizados sobre desvios indesejados na amostra estão disponíveis ao público. ${ }^{11}$ Aqui só é pertinente apontar que, ademais da aplicação dos mesmos critérios na definição da amostra nas duas cidades, a administração do fluxo de entrevistas seguiu critérios de saturação segundo diferentes tipos de organizações civis. Assim, se o peso das mesmas na amostra não guarda qualquer relação estatística com a composição de um universo (desconhecido) de organizações civis, os resultados para cada tipo (saturado) de organização civil são indicativos de suas características e comportamentos.

Em duas perguntas abertas sucessivas, solicitou-se aos entrevistados que especificassem o grupo de pessoas para o qual a entidade trabalhava e se esta se considerava representante do grupo definido previamente; só depois, e em caso de a resposta à segunda pergunta ser afirmativa, perguntou-se "por que", isto é, os motivos pelos quais a organização afirmava representar os interesses dos beneficiários. A partir do exame e da codificação da última pergunta, noções foram cuidadosamente sistematizadas em uma tipologia empírica composta por categorias dotadas de coerência interna e com certo grau de abstração. ${ }^{12}$

\section{DOIS UNIVERSOS DE ORGANIZAÇÕES CIVIS}

A análise requer identificar e tornar comparáveis as organizações civis oriundas de dois contextos nacionais e metropolitanos distintos. Os

${ }^{11}$ Vide a nota de rodapé 9, e Houtzager, Gurza Lavalle e Acharya, 2003.

12 A representação presuntiva será aqui examinada somente mediante estatísticas descritivas, mas, em outros trabalhos, ela recebeu tratamento sistemático como variável dependente no campo das estatísticas inferenciais, especificamente utilizando-se estimativas de probabilidade (relative risk ratios e logistic regressions).

Para uma exposição mais técnica, vide os anexos em Gurza Lavalle, Houtzager e Castello 2005, e Houzager, Gurza Lavalle e Acharya 2003. Vide, também, Gurza Lavalle, Houtzager e Castello 2006b. 
rótulos normalmente utilizados para distinguir atores coletivos costumam ser objeto de disputa simbólica com relação ao sentido atribuído à sua atuação. ${ }^{13}$ Por isso, as organizações civis não foram classificadas com base em suas autodefinições, e sim conforme critérios objetivos de dois tipos: a relação com seus beneficiários e o perfil das atividades normalmente realizadas. No primeiro caso, (i) o conjunto dos beneficiários encarna uma unidade real ou abstrata (por exemplo, os moradores do bairro ou os cidadãos, respectivamente), (ii) cujos componentes são indivíduos, organizações e atores coletivos, ou segmentos da população, (iii) concebidos como membros ou sócios, como público objetivo ou como a comunidade. No segundo caso, a cada tipo de organização civil corresponde (iv) uma estratégia de atuação distintiva e (v) combinações excludentes de atividades dirigidas a reivindicação e mobilização, oferta de serviços, organização popular ou intermediação entre o governo e os beneficiários.

Mediante a aplicação desses critérios, foi possível delinear uma primeira classificação de organizações civis, cujos aspectos ficam intuitivamente claros pelas denominações aqui utilizadas: associações de bairro, associações comunitárias, ONGs, pastorais, articuladoras, fóruns e entidades assistenciais. As caracterizações comuns na literatura dos tipos de organizações civis aqui examinados e a consistência da tipologia podem ser consultadas em outros trabalhos (Gurza Lavalle; Castello; Bichir, 2007; 2008). Contudo, as articuladoras e as associações comunitárias merecem um breve comentário, pois são organizações civis com características menos intuitivas do que as demais. As primeiras são entidades criadas por outras organizações especificamente para coordenar sua ação e defender seus interesses frente ao Estado e a outros atores econômicos e societais; as segundas são atores locais e territoriais de solidariedade mútua ou que trabalham com pequenos

${ }^{13}$ Além disso, a elaboração de uma identidade pública e a aceitação de determinados perfis organizacionais compartilhados costumam ser desafios complexos para as organizações civis que, às vezes, seguem caminhos tortuosos para fazer frente a eles, como mostra a história das ONGs no Brasil (Landim, 1998). grupos e comunidades nos quais os beneficiários e os membros da organização coincidem (grupos da terceira idade, clubes locais de jogadores de bocha, escolas de samba, centros da juventude, entre outros).

A composição dos universos das organizações civis coincide em boa medida na Cidade do México e em São Paulo, mas a correspondência não se dá ponto por ponto, nem seria razoável esperar que assim fosse. Uma vez resolvida a classificação inicial, optou-se por criar categorias mais abstratas, que permitissem ampliar a comparabilidade entre os países e o diálogo com a literatura internacional. A Tabela 1 apresenta a tipologia final adotada para esta análise e as classificações iniciais nas quais não há correspondência. Vale a pena recordar que as amostras foram geradas seguindo-se procedimentos iguais em ambas as cidades, ou seja, os pesos específicos dos diferentes tipos de entidades foram afetados da mesma maneira pelas opções metodológicas adotadas e, por conseguinte, as semelhanças e variações em sua composição obedecem aos contextos investigados.

Com relação às não-correspondências, deve-

Tabela 1 - Organizaçóes civis em duas metrópoles

\begin{tabular}{|c|c|c|c|c|}
\hline \multirow[t]{2}{*}{ Tipologia Agregada } & \multicolumn{2}{|c|}{ São Paulo } & \multicolumn{2}{|c|}{$\begin{array}{l}\text { Cidade do } \\
\text { México }\end{array}$} \\
\hline & $\mathbf{N}$ & $\%$ & $\mathbf{N}$ & $\%$ \\
\hline $\begin{array}{l}\text { Associações de } \\
\text { base }\end{array}$ & 53 & 23,1 & 52 & 26,5 \\
\hline $\begin{array}{l}\text { Associações de } \\
\text { bairro }\end{array}$ & 33 & 14,4 & 6 & 3,1 \\
\hline $\begin{array}{l}\text { Associações } \\
\text { comunitárias }\end{array}$ & 18 & 7,9 & 6 & 3,1 \\
\hline $\begin{array}{l}\text { Comitês de } \\
\text { vizinhos }\end{array}$ & - & - & 40 & 20,4 \\
\hline $\begin{array}{l}\text { Organizações } \\
\text { orientadas } \\
\text { tematicamente }\end{array}$ & 69 & 30,1 & 77 & 39,3 \\
\hline ONGs & 62 & 27,1 & 73 & 37,2 \\
\hline Pastoral & 7 & 3,1 & - & - \\
\hline $\begin{array}{l}\text { Entidades de } \\
\text { coordenação }\end{array}$ & 47 & 20,5 & 24 & 12,2 \\
\hline Articuladoras & 33 & 14,4 & 22 & 11,2 \\
\hline Fóruns & 12 & 5,2 & - & - \\
\hline $\begin{array}{l}\text { Entidades } \\
\text { assistenciais }\end{array}$ & 38 & 16,6 & 28 & 14,3 \\
\hline Outras & 22 & 9,6 & 15 & 7,7 \\
\hline Total & 229 & 100 & 196 & 100 \\
\hline
\end{tabular}


se prestar atenção a três tipos de organizações. As associações de base na Cidade do México teriam presença modesta na amostra se não fosse pela explosão dos comitês de vizinhos, gerada pela Lei de Participação Cidadã. ${ }^{14}$ Por sua vez, a teologia da liberação e o ativismo da Igreja Católica no Brasil perderam força depois da transição, mas o trabalho pastoral ainda se encontra suficientemente disseminado para aparecer na amostra. O trabalho de coordenação horizontal e de condensação de agendas comuns entre constelações de atores vinculados por afinidades temáticas também parece mais difundido em São Paulo, a julgar pela ausência de fóruns na capital mexicana. Em termos gerais, contudo, a composição da amostra guarda proporções semelhantes, seja nas subcategorias compatíveis ou nas categorias agregadas (associações de base, organizações orientadas tematicamente, entidades de coordenação e entidades assistenciais).

\section{A DUPLA FACE DA ACCOUNTABILITY SOCIETAL NAS DUAS METRÓPOLES}

As razões citadas pelos distintos tipos de organizações civis para justificar a representação presuntiva compõem grandes constelações de sentidos, e a tipologia as adensa e sistematiza seus elementos centrais. Assim, a tipologia de argumentos de representação presuntiva é resultado da investigação, prescinde de elementos conceptuais normativos apriorísticos que operam como parâmetros dedutivos e, em princípio, nada signi-

${ }^{14}$ Embora se possa argumentar que os comitês de vizinhos não pertencem à sociedade civil, sua exclusão remeteria a uma compreensão normativa da sociedade civil em que se postulam características distintivas como autonomia, espontaneidade e inserção genuína no tecido social. Aqui, evitamos intencionalmente essas compreensões normativas (para um exame crítico das formulações altamente estilizadas e normativamente sobrecarregadas da sociedade civil que dominaram o debate durante os anos 1990, vide Gurza Lavalle, 2003a). Ademais, a técnica de bola de neve foi desenhada com o propósito de gerar cadeias de referências originadas a partir de organizações civis reconhecidas por seu trabalho e atividade em bairros pobres das duas cidades, ou seja, entrevistaram-se os atores localmente relevantes quando e onde foram encontrados. Assim, os comitês de vizinhos constantes na amostra são resultado do reconhecimento de outros atores locais de sua presença ativa e do valor do seu trabalho. fica em relação à forma como as organizações civis deveriam construir suas funções de representação política. Claro que isso não impede, antes possibilita, a avaliação das implicações dos argumentos apresentados do ponto de vista de sua compatibilidade com exigências democráticas inescapáveis. Nesse caso, o interesse na eventual presença de mecanismos de accountability leva a enfocar, na definição da tipologia, o modo em que se conjugam as relações entre representado e representante, e entre o representante e o lócus da representação, sempre em busca de sua capacidade para animar e sustentar modalidades de controle social. $\mathrm{O}$ lócus, convém precisar, é, ao mesmo tempo, a instância na qual a representação é exercida e os interlocutores frente aos quais se exerce, notoriamente o poder público, mas não só ele, também outros atores da sociedade civil e, em última instância, a sociedade como um todo. Cada argumento constitui uma modalidade particular de ordenação das relações entre representante, representado e lócus, cuja nota distintiva é a ênfase depositada pela organização civil em determinadas características dessas relações, as quais ela invoca como prova da autenticidade da representação presuntiva.

Na metrópole sul-americana, 73\% das organizações civis se consideram representantes de seus beneficiários, ao passo que a representação presuntiva, na Cidade do México, chega a 58\% da amostra. As razões apresentadas pelas organizações civis definem seis argumentos de justificação presentes nos dois contextos: eleitoral, de identidade, de filiação, de serviços, de proximidade e de intermediação. Os três primeiros são conhecidos ou constitutivos da história da democracia moderna e costumam receber tratamento no campo das teorias da representação, mas aparecem em posição francamente secundária como justificações do caráter genuíno da representação exercida pelas organizações civis estudadas, oscilando entre 4\% e 15\% (Gráfico 1). Enquanto isso, os argumentos mais invocados - serviços, proximidade e intermediação - correspondem plenamente a modalidades de representação presuntiva, resultam 
Gráfico 1 - Argumentos de representação presuntiva

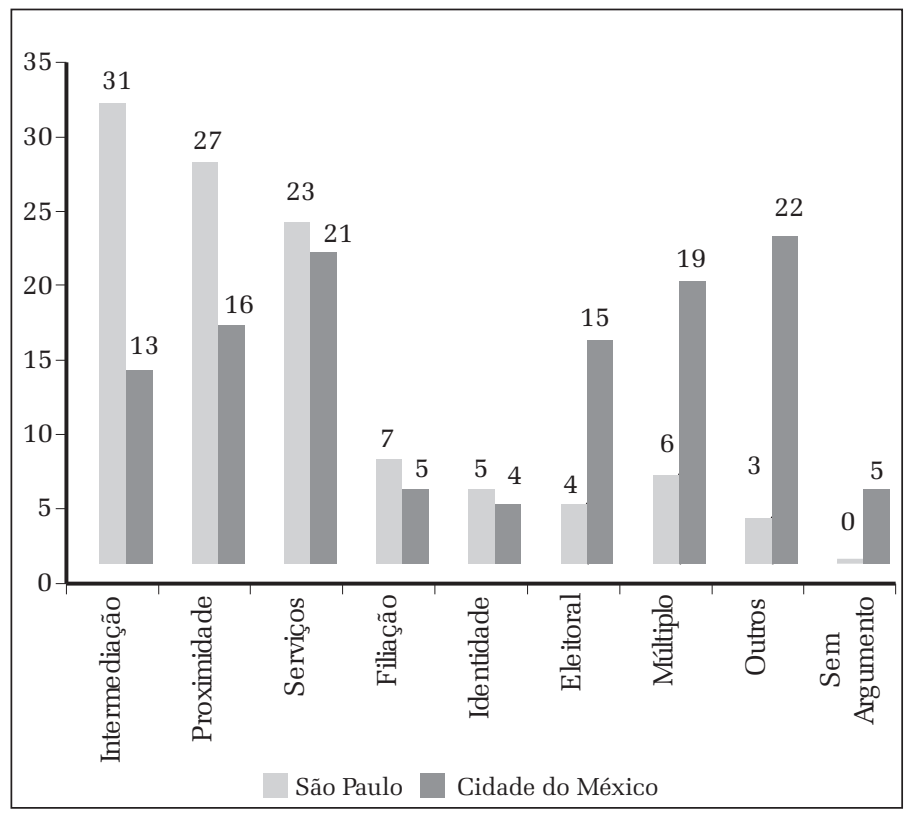

vis de São Paulo. Nesse artigo, os argumentos serão brevemente resumidos para dar passagem à comparação e, principalmente, à especificação de suas conseqüências do ponto de vista da dupla face da accountability societal. ${ }^{15}$

Convém iniciar destacando as diferenças no grau de estabilização dos argumentos nas duas cidades, revisando as cifras do Gráfico 1 correspondentes à presença de argumentos múltiplos, residuais e inclassificáveis como justificativas de representação. $\mathrm{O}$ fato de que a esmagadora maioria das organizações civis paulistanas (94\%) recorra a um só argumento, enquanto $19 \%$ das entidades mexicanas lançam mão de vários deles simultaneamente, sugere em parte estranhos à tradição democrática e não são necessariamente compatíveis com exigências democráticas mínimas. Paradoxalmente, dentro desse segundo conjunto, também se encontram os argumentos mais novos e promissores. No terreno comparativo, os resultados de ambas as metrópoles contrastam e permitem esboçar padrões nitidamente diferenciados, comimplicações relevantes não só para as teorias democrática e da sociedade civil, mas também para a compreensão das capacidades e repertórios de ação dos atores em questão. Aqui trataremos somente das primeiras implicações. Os Gráficos 1 e 2 sintetizam os resultados comparativos da tipologia de argumentos, bem como sua relação com os diferentes tipos de organizações civis que os utilizam nas duas cidades.

Os seis argumentos foram expostos sistematicamente a propósito de um exame das práticas de representação política das organizações ci- a presença de formulações relativamente mais estabilizadas no primeiro contexto. Além disso, entre as entidades da Cidade do México, um número superior a $10 \%$ utiliza três argumentos ou mais, enquanto, em São Paulo, só 1\% da amostra usa três argumentos. Isso está em sintonia com a gran-

Gráfico 2 - Representação Presuntiva segundo o Tipo de Organização Civil - São Paulo

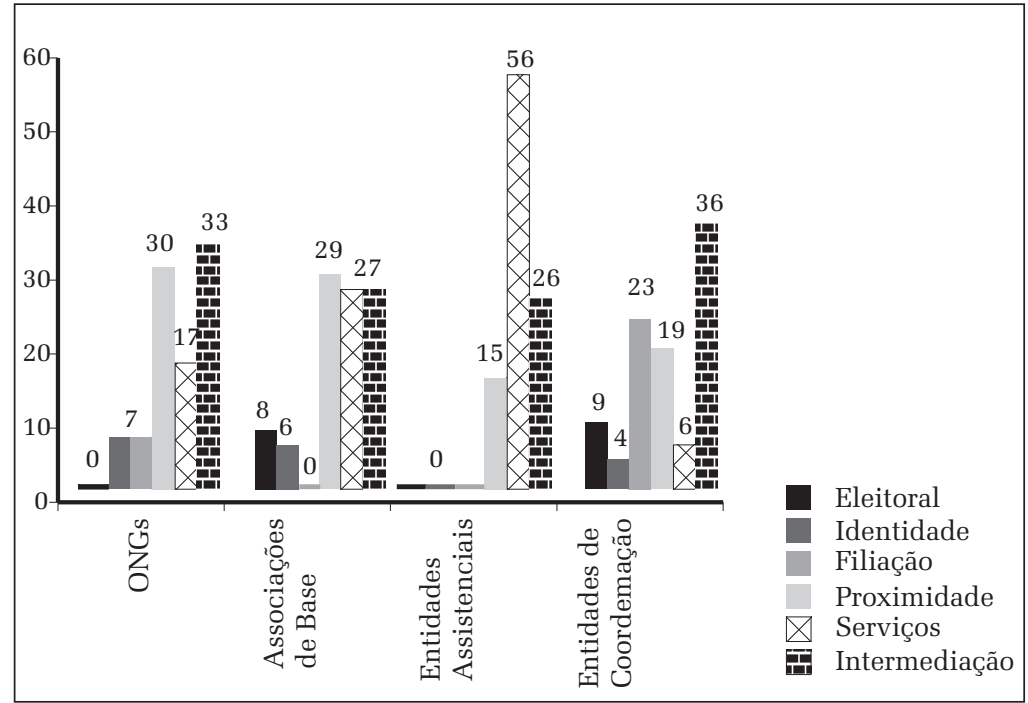
gumentos em Gurza Lavalle, Houtzager e Castello (2006b). 
Gráfico 3 - Representação Presuntiva segundo Tipo de Organização Civil - Cidade do México

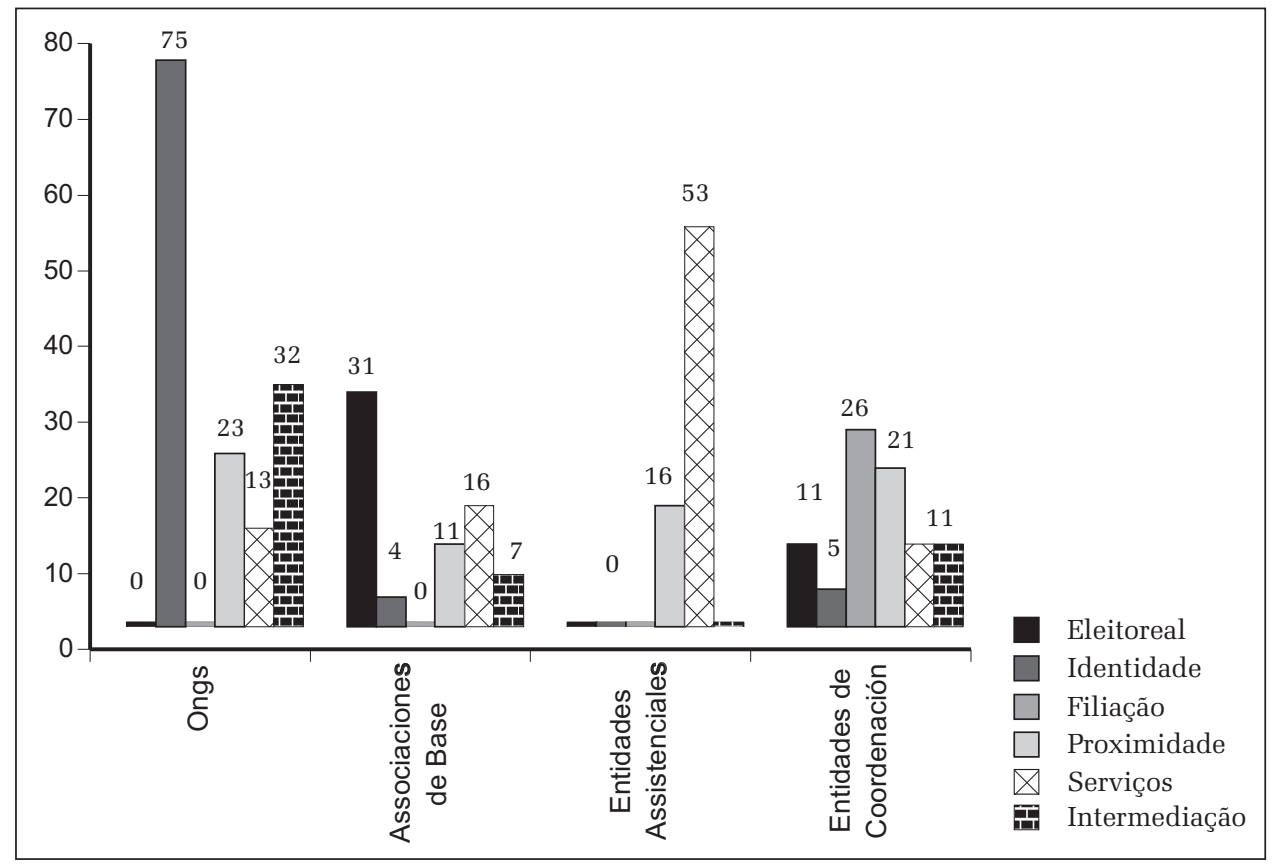

de dispersão de argumentos de representação presuntiva encontrada na capital mexicana, cuja taxa é sete vezes superior à de São Paulo; em outras palavras, $22 \%$ dos argumentos citados pelas organizações civis mexicanas são residuais, pois não foram suscetíveis de classificação na tipologia de argumentos nem apresentaram semelhanças suficientes para configurar outro argumento. Por sua vez, na cidade brasileira, a categoria residual "outras" compreende somente 3\% das entidades da amostra. Por último, também não foi possível classificar como argumentos de representação presuntiva, vale dizer, como justificativas de legitimidade, 5\% das formulações pronunciadas pelas organizações civis da Cidade do México. A rigor, a categoria "sem argumento" compreende respostas que, mesmo segundo critérios generosamente amplos, não configuram uma justificativa com relação ao beneficiário. Na amostra de São Paulo, não houve sequer uma entidade agrupada nessa categoria.

No argumento eleitoral, as organizações civis invocam a existência de mecanismos de eleição dos líderes ou dirigentes como evidência de sua representatividade. ${ }^{16} \mathrm{O}$ lócus implícito como pano de fundo são os diversos órgãos do poder público, mas o argumento não contempla nem explicita as funções que serão desempenhadas. Uma porcentagem muito pequena de organizações civis em São Paulo, só 4\%, argumenta que a existência do voto como mecanismo da eleição de líderes ou membros das direções constitui uma evidência contundente da legitimidade da representação presuntiva. A cifra é quase quatro vezes mais alta na Cidade do México (15\%), em boa medida devido aos efeitos da Lei de Participação Cidadã na explosão de comitês de vizinhos e na conseqüente adoção e generalização de uma forma organizativa específica reconhecida e regulamentada pela lei.

As eleições são o mecanismo mais conhecido e estudado de autorização e de accountability. Embora estejam longe de ser sinônimos de representatividade, como demonstram os debates

${ }^{16}$ Por motivos óbvios, esse argumento cai no terreno bem definido na literatura especializada sob rubricas como governo representativo (Manim, 1995), mandato representativo (Sartori, 1962), accountability eleitoral (Przeworski, Stokes e Manim, 1999), representacão eleitoral, conceito de representação acting for, ou "agir em nome de" (Pitkin, 1985 [1967]), modelo de congruência ou representação política moderna (Galvão, 1971). 
na literatura especializada, ${ }^{17}$ elas oferecem mecanismos de controle e sanção sobre os representantes e tendem a estimular sua sensibilidade frente às demandas e necessidades dos representados (responsividade). Apesar de carecerem do escrutínio público e do grau de formalização próprios dos processos eleitorais do governo representativo, as eleições no seio de organizações civis seguem a mesma fórmula e os mesmos critérios de legitimidade. Nesse sentido, não se trata de uma modalidade de representação presuntiva, e sim de expedientes de representação autorizados. Se as organizações civis que exercem funções de representação se encontram submetidas a mecanismos eleitorais em sua relação com os beneficiários, uma das duas faces da accountability societal - a do controle dos controladores - responde plenamente a exigências democráticas. A baixa freqüência da representação autorizada, que seria ainda menos expressiva se não fosse pelo peso dos comitês de vizinhos nas associações de base da Cidade do México, está em sintonia com as preocupações da literatura com a legitimidade das organizações civis no desempenho de seu papel de intermediárias entre distintos interesses sociais e o poder público. Como o campo da representação de interesses pelas associações de base é relativamente pouco estruturado e regulamentado, a outra face da accountability, ou a relação entre o representante e o lócus da representação, é pouco clara; vale dizer, a gama de funções permitidas ao primeiro e as fronteiras do segundo não estão especificadas nem são óbvias a ponto de dispensar essas especificações.

No argumento de identidade as organizações invocam uma coincidência substantiva plena entre o representante e o representado em virtude de características existenciais - gênero, raça, origem étnica - como base da legitimidade da representação por elas exercida. ${ }^{18}$ Não existem expedientes

${ }^{17}$ Não apenas as numerosas denúncias da impotência dos partidos para resolver o déficit de representação das democracias contemporâneas (Chalmers; Martim; Piester, 1997; Friedmam; Hochstetler, 2002; Roberts, 2002), como também diagnósticos agudos acerca das limitações estruturais do voto ou mecanismo eleitoral e do parlamento como lócus da representação para garantir a responsividade e o controle dos representantes eleitos (Sartori, 1962; Manin, Przeworski; Stokes, 1999b). de autorização e o lócus permanece implícito, ou seja, representam-se interesses animados por uma lógica identitária frente aos demais e em instâncias implicitamente consideradas pouco sensíveis às demandas dos grupos portadores dessas identidades. As dinâmicas da representação exercida por organizações civis parecem pouco ou nada guiadas por lógicas identitárias, tanto em São Paulo (5\%) quanto na Cidade do México (4\%). Embora apenas as entidades assistenciais prescindam totalmente de reivindicações de legitimidade centradas na identidade, $o$ argumento é igualmente irrelevante para todos os tipos de organizações civis. Dentro de sua presença limitada no conjunto de argumentos, chama a atenção que a justificação baseada na identidade seja a mais utilizada pelas ONGs na capital mexicana (quase 75\%), ao passo que em São Paulo ela aparece dispersa e com presença igualmente baixa em todos os tipos de organizações civis.

Na medida em que o argumento de identidade se baseia nos efeitos atribuídos a semelhanças existenciais ou substantivas, descuidam-se os mecanismos de controle e sanção, pois, em princípio, a semelhança existencial encerraria tudo o que o representante deve ser para atuar conforme espera o representado. Assim, o eventual controle social do representante se torna supérfluo pelo tipo de coincidência substantiva pressuposta no argumento. A questão da dupla face da accountability societal emerge com força: não apenas as faculdades e responsabilidade no lócus da representação são pressupostas sem qualquer especificação, mas também pouco se pode compensar a ausência de autorização e de mecanismos de controle com a introdução de pressupostos tão controversos como a derivação hipotética de condutas - do representante - mediante a postulação de coincidências substantivas. Mesmo assim, quando o pressupos-

${ }^{18} \mathrm{O}$ argumento de identidade encontra eco na literatura sob formulações diversas: conceito de representação standing for (pôr-se em lugar de)(Pitkin 1985 [1967]), representação de minoria (Young 2002), representação espelho ou descritiva, identitária e, inclusive, em parte das posturas que defenderam historicamente a introdução da representação proporcional como critério de composição do parlamento (Pitkin, 1985 [1967]). 
to da relação direta entre características existenciais do representante e suas escolhas ou sua atuação é suficientemente flexibilizado, torna-se plausível atribuir a tais características certo olhar ou uma perspectiva (Young, 2002, p.153) - de gênero ou de raça, para citar dois exemplos óbvios - que, de forma ampla, ou seja, sem pressupor interesses ou opiniões pré-definidas, tenda a colocar em discussão problemas pertinentes aos grupos sociais considerados como indesejavelmente sub-representados. É conveniente observar que, sob tal perspectiva, o argumento também permite vislumbrar quão mais ampla é a medida da democratização em relação ao parâmetro da dupla face da accountability societal e como essa última é uma tentativa de introduzir formas e institucionalizar restrições que reduzam a contingência e os riscos inerentes a essa amplitude.

No argumento de filiação, as organizações civis invocam a afiliação de seus membros como evidência de sua legitimidade e enfatizam implícita ou explicitamente a gênese simultânea da própria organização e dos interesses por ela representados. Trata-se não apenas de entidades criadas especificamente para representar os indivíduos ou atores coletivos envolvidos em sua criação, mas também, e, sobretudo, de organizações civis que representam interesses delimitados e instituídos mediante o ato de sua própria fundação. ${ }^{19}$ Assim sendo, representado e representante são gerados no mesmo processo. Nesse argumento, o lócus é um elemento imprescindível, visto que a fundação de um ator com propósitos de representação só adquire sentido pela existência de instâncias e interlocutores pré-definidos (na maioria dos casos, o poder público, mas também outros atores e instâncias privados ou societários). Ilustrativamente, os sindicatos supõem a interlocução tripartite entre trabalhadores, poder público e patrões, assim como a existência de regulação e de instâncias de

${ }^{19} \mathrm{O}$ argumento de filiação corresponde a um conjunto de práticas de representação que admitiram leituras positivas e negativas em relação a seus efeitos sobre a democracia: representação funcional ou corporativa, ou inclusive a idéia de membership nas propostas de democracia associativa. negociação. O argumento de filiação também é francamente minoritário, sendo invocado por 7\% das organizações civis paulistanas examinadas e por $5 \%$ das mexicanas. Não obstante e apesar de seu peso modesto na amostra nos dois contextos, trata-se do principal argumento das entidades de coordenação (São Paulo - SP -: 23\%; Cidade do México - MX -: 26\%); isto é, concentra-se quase que exclusivamente nesse tipo de organização. Levando-se em conta que a filiação guarda estreita vinculação com determinadas formas e funções organizativas, não deve surpreender tal concentração em entidades fundadas por outras entidades com vistas a representar seus interesses e a coordenar sua atuação.

Aqui também se lança mão de razões de facto e, a respeito disso, a semelhança com o argumento eleitoral não é fortuita, remetendo à corporativização de interesses em sindicatos ao longo do século XX. Nenhum dos dois constitui, obviamente, argumento desenvolvido para lidar com os dilemas da representação presuntiva, pois os dispositivos de autorização são prévios e desempenham simultaneamente o papel de mecanismos de controle (voto e afiliação). Seja devido às cotizações e a outras formas de contribuição monetária, seja à participação na eleição da direção, ou ainda à ameaça latente do direito de saída, ou por outros mecanismos de sanção e controle freqüentemente associados à noção de afiliação ou membership, o argumento pressupõe mecanismos para fixar e manter relações de controle social entre a organização e seus beneficiários. Por sua vez, a outra face da accountability societal aparece garantida com maior solidez que em qualquer outro argumento, pois a fundação da organização por aqueles que serão seus membros implica a especificação das funções e do domínio da representação. Não é de estranhar que a idéia de uma democracia de associações tenha sido explorada no campo da teoria democrática privilegiando associações baseadas na filiação devido, precisamente, à presença de mecanismos de controle societal internos e à especificação das fronteiras e da matéria da delegação (Cohen, 1995; Warren, 2001). 
No argumento de serviços, as organizações civis invocam benefícios outorgados a seus públicos-alvo como fonte de sua legitimidade, ou seja, enfatizam que sua atuação melhora a vida das pessoas, normalmente mediante a prestação de serviços. ${ }^{20} \mathrm{~A}$ relação entre representante e representado ou beneficiário é de índole unilateral e se consubstancia na concessão de um benefício. A maior singularidade do argumento reside em que o lócus nem ao menos aparece levemente insinuado ou, de modo mais direto, é omitido por completo. A bondade da concessão de benefícios invocada é apresentada como auto-evidente, sem que a origem desses benefícios apareça como resultado de uma intermediação perante alguém ou alguma instituição em nome dos eventuais beneficiados. Trata-se de um dos três argumentos mais utilizados nas duas cidades, que alcança níveis um pouco superiores a vinte pontos percentuais (SP: 23\%; MX: 21\%), e também o único claramente associado a um tipo de organização civil. $\mathrm{Na}$ realidade, mais da metade das entidades assistenciais na metrópole sul-americana (56\%) e na capital mexicana (53\%) invocam benefícios como justificativa da legitimidade da representação presuntiva por elas assumida. No entanto, cabe observar que todos os tipos de organização lançam mão dessa justificativa nas duas cidades e que, em São Paulo, as associações de base a utilizam com freqüência considerável (27\%), em nível superior ao que ocorre na Cidade do México (16\%).

Esse argumento opera uma sinonímia entre a capacidade de distribuir ou produzir benefícios reais e a sinceridade do compromisso de representar para o bem dos beneficiários, sugerindo, diga-se de passagem, uma crítica à representação política tradicional, por sua incapacidade de fazer uma diferença real - de solucionar problemas e necessidades dos representados ou de corresponder a suas expectativas. Dado que a efi-

${ }^{20}$ Esse argumento poderia ser classificado nas concepções parciais de representação de Pitkin (1985 [1967] p.123156) como uma noção substantiva (distribuir benefícios), embora, devido às características expostas na análise do argumento, é difícil enquadrá-lo dentro da lógica do acting for que, segundo a autora, corresponde às modalidades de representação substantiva. cácia aparece como peça-chave do argumento, a justificativa é especialmente vulnerável a todas as advertências formuladas na teoria democrática contra concepções não-procedimentais (substantivas e igualitárias) da democracia. Mas aqui só interessam suas implicações do ponto de vista da questão da dupla face da accountability societal. Em primeiro lugar, o argumento não contempla mecanismos de controle ou sanção societal dos representantes, e os representados figuram em posição dependente, como receptores de uma concessão. Em teoria, seria possível pensar nas eventuais opções do beneficiário, quer dizer, na capacidade de mudar de benfeitor, e nos mecanismos de indução sobre o representante, associados a essa capacidade. Mas, como se trata de um beneficio "gracioso", os efeitos de uma possível concorrência entre representantes parecem nulos no caso das entidades assistenciais e reduzidos no das associações de bairro - a não ser em condições de disputa territorial de beneficiários, no caso das últimas. Em segundo lugar, visto que a justificativa reside em proporcionar diretamente benefícios, no argumento aparece cancelada a função de intermediação e, portanto, o lócus. Mais precisamente, o argumento oculta a intermediação inerente a todas as práticas de representação, pois a ênfase na concessão de benefícios opera sem que a origem ou o lócus de negociação ou obtenção dos mesmos apareça ao menos insinuado. A ausência de intermediação e do lócus anula a essência da representação e o próprio sentido do controle dos controladores.

No argumento da proximidade as organizações civis enfatizam a qualidade de sua relação com os beneficiários, invocando vínculos marcados pela contigüidade e horizontalidade como demonstração de seu interesse e seu papel genuíno de representantes. A proximidade pode permitir modalidades "frágeis" de controle social, não reconhecidas formalmente como tal. Existe um lócus sugerido no argumento, pois as organizações que o invocam enfatizam seu compromisso de favorecer o protagonismo e a capacidade de reivindicação e resolução de problemas dos beneficiários, o 
que remete a algum interlocutor pressuposto. Mesmo assim, como em todos os argumentos de representação presuntiva, as faculdades e funções do representante no lócus da representação carecem de especificação - ainda que somente no caso do argumento de serviços o lócus desapareça por completo. A justificativa é das mais utilizadas em São Paulo (27\%), ao passo que, na Cidade do México, é menos comum (16\%), permanecendo no mesmo nível do argumento eleitoral. Na primeira metrópole, a proximidade como fonte de legitimidade é invocada principalmente por ONGs (30\%) e associações de base (30\%), e, na segunda, por ONGs (23\%) e entidades de coordenação (21\%), mas todos os tipos de entidades utilizam esse argumento nos dois contextos.

A este argumento subjaz uma crítica implícita à representação política eleitoral, e tal crítica anima uma resposta que contempla, em alguma medida, o controle social. No que tange à crítica, acusam-se as distorções causadas pelas estruturas institucionais de intermediação política eleitoral, assumidas como incapazes de transmitir com fidelidade a voz e os anseios da população. A resposta, por sua vez, baseia-se nas virtualidades positivas da proximidade (física) e da participação. Participação e proximidade física constituem, em principio, condições favoráveis ao reforço da relação entre representantes e representados, viabilizando algumas formas de controle ou sanção, a começar pela verbalização direta de demandas ou insatisfações, e pela capacidade dos beneficiários de impor aos representantes perdas de prestígio na localidade. A face da accountability societal entre o representante e o lócus da representação é tão ambígua como desestruturado é o campo da representação de interesses ocupado pelas organizações civis. Mais além, à ausência de especificação das funções do representante é preciso acrescentar que o argumento valoriza o protagonismo do beneficiário como caminho para eliminar as intermediações e, nessa perspectiva, a própria idéia de “representação” perde o sentido.

O argumento de intermediação faz com que a legitimidade da organização civil não dependa da relação com os beneficiários, e sim do lócus da representação, ou seja, confere à intermediação em si a posição de fundamento da autenticidade do papel desempenhado pelo representante. ${ }^{21}$ As funções de intermediação levadas a cabo pela entidade conseguem abrir as portas e franquear o acesso a instâncias de tomada de decisões no poder público, as quais, de outra forma, permaneceriam inalcançáveis para os beneficiários. Assim, a dupla face da accountability societal aparece invertida em relação aos outros argumentos, ou seja, nesse caso, a relação com o lócus é particularmente clara, ao passo que a relação com o representado é a que permanece totalmente difusa, além de se repetir a ausência de expedientes de autorização. $\mathrm{O}$ exercício de uma intermediação assim entendida constitui a justificativa mais invocada em São Paulo (31\%), ocupando uma posição bem mais modesta na Cidade do México (13\%), inferior à dos argumentos de serviços, de proximidade e eleitoral. A freqüência com que os diferentes tipos de organizações civis lançam mão do argumento é igualmente contrastante: por um lado, em São Paulo, ele constitui a primeira ou segunda justificativa mais utilizada por todos os tipos de entidades aqui contempladas (apresentando cifras que oscilam entre $26 \%$ e $36 \%$, segundo o tipo de organização considerado), ao passo que, por outro lado, na capital mexicana só as ONGs utilizam majoritariamente esse argumento (23\%), enquanto, para os demais tipos de entidades, a justificativa é marginal ou nula.

Em relação à dupla face da accountability societal, o argumento se mostra invertido e particularmente preciso em um dos flancos, quando comparado com os outros. Por um lado, a importância conferida à intermediação perante o Estado vem associada à especificação das funções do representante no lócus, ou seja, à explicitação do tipo de controle que o representante realiza ou aspira a realizar sobre as instituições políticas. $\mathrm{O}$ ar-

\footnotetext{
${ }^{21}$ Trata-se de um argumento bastante inovador. Como o argumento de serviços, corresponde claramente à família das concepções de representação substantiva, mas, nesse caso, responde de modo pleno à lógica do acting for (Pitkin, 1985 [1967] p.123-156).
} 
gumento estabelece como ponto de partida a urgência de aliviar uma desigualdade que não é diretamente de renda, e sim de acesso ao Estado; isso implica, do ponto de vista do ator, não apenas assumir que se possui um posicionamento privilegiado na desigual distribuição da capacidade de acesso ao Estado, como também um compromisso de utilizar essa capacidade para levantar a voz daqueles que, de outra forma, não seriam escutados. Entretanto, a outra face da accountability societal é bastante vulnerável. Não existe, no argumento, nenhum indício de controle social sobre o representante, sequer sob a pressuposição de alguma coincidência substantiva ou simbólica, como ocorre no argumento da identidade. As organizações civis verbalizam interesses ou opiniões de eventuais beneficiários, pressupondo que os propósitos e eventuais efeitos de sua intermediação sejam louváveis ou, ao menos, publicamente defensáveis.

\section{PERSPECTIVAS DA ACCOUNTAVILITY SOCIETAL}

Os resultados examinados nestas páginas apresentam variações importantes entre as duas cidades. Explorá-las exigiria outro tipo de abordagem, atenta às variáveis contextuais e menos preocupada com os deslocamentos analíticos recentes na teoria democrática. Esse esforço foi realizado em outras oportunidades e atentou para as diferenças genealógicas mediante o exame dos processos de construção política das sociedades civis nas duas cidades (Gurza Lavalle; Houtzager; Castello 2005b; Gurza Lavalle; Houtzager; Acharya 2005). ${ }^{22}$ Em geral, na Cidade do México, algumas experiências participativas foram desenvolvidas a partir das administrações locais do PRI na década de 80, foram redefinidas e, em alguns aspectos, ampliadas pelos governos do PRD (Sánchez-Mejorada; Álvarez, 2002). Em poucos casos, essas experiências foram institucionalizadas e introduzidas sis-

${ }^{22}$ Dobrowolsky e Jensom (2002) analisaram um processo semelhante, no caso da representação política exercida por organizações de gênero no Canadá. tematicamente na produção de políticas públicas e, salvo raras exceções, só foram convocadas algumas organizações civis para participar de espaços ad hoc com funções consultivas. Na verdade, os esforços de mobilização social e de criação de novos atores, característicos do período de transição, não se sedimentaram em espaços ou inovações capazes de resguardar institucionalmente o protagonismo momentâneo conquistado pelas organizações civis; tampouco, portanto, estimularam o desempenho de práticas de representação presuntiva nem a correlativa decantação de argumentos justificativos precisos ou novos. Contudo, esses esforços certamente deixaram um legado institucional inédito em termos mundiais, com a criação do Instituto Federal Eleitoral, e abriram caminho para que diferentes atores continuem disputando inovações institucionais para ampliar os controles democráticos sobre o poder público; a Lei de Transparência e o Instituto Federal de Acesso à Informação Pública (IFAI) são exemplos claros disso.

Em São Paulo, as organizações civis construíram novas modalidades de representação política dentro da administração pública subordinada ao poder executivo nos planos federal, estadual e municipal. A inovação mais notável são os conselhos gestores de políticas públicas, cujos alicerces institucionais, uma vez sancionados pela Constituição de 1988, sedimentaram-se no contexto póstransição, mediante sua regulamentação e implementação em distintas políticas setoriais durante os últimos quinze anos. Os governos locais podem ser mais ou menos favoráveis, e até contrários, ao funcionamento dessas modalidades de representação política pela via das organizações civis, mas, definitivamente, não está em suas mãos banir sua existência. Além da estrutura dos conselhos em diferentes áreas de políticas com mandato constitucional, a multiplicação de fórmulas de cogestão animadas pela reforma do Estado dos últimos anos e a expansão das experiências de orçamento participativo por todo o território do Brasil - experiência que estava sendo implantada em SP no momento da investigação - vieram a reforçar as 
funções de representação política desempenhadas por organizações civis. A magnitude dessas novas funções parece ter animado uma progressiva decantação de argumentos mas precisos de representação presuntiva, assim como uma maior proliferação do argumento mais novo, a saber, o de intermediação.

No terreno analítico da teoria democrática, privilegiado nestas páginas, os argumentos de representação presuntiva examinados expressam as justificativas invocadas pelas distintas organizações civis para sustentar publicamente a legitimidade de suas práticas de representação, apesar e, precisamente, diante da inexistência de um componente sine qua non do modelo de representação política consagrado nas democracias: a autorização. Foram encontrados seis argumentos recorrentes, invocados pelas organizações civis na Cidade do México e em São Paulo. Isso sugere que o conjunto das práticas de representação exercidas por esses atores, incluindo o repertório de eventuais mecanismos de controle social, é, pelo menos, tão diversificado quanto os tipos de argumentos animados por essas práticas, evidenciando os custos cognitivos das posturas que emitem veredictos homogêneos a priori sobre a (in) compatibilidade entre a representação política democrática e as atividades características das organizações civis.

Os argumentos de representação presuntiva organizacional das associações civis ao campo da teoria democrática. Assim, seria possível especificar que características das organizações civis favorecem efeitos desejáveis quando se envolvem em funções de controle sobre o poder público e de representação de seus beneficiários, ou, nas palavras de Warren (2004), seria possível determinar que "sociedade civil é [ou tende a ser] boa para a democracia".

Dos resultados acerca das duas faces da accountability societal serão extraídas apenas as conseqüências acerca da face do controle dos beneficiários, isto é, relativa aos déficits ou à franca inexistência de legitimidade das organizações civis que exercem funções de representação. Os tipos de entidades mais tradicionais - como as assistenciais e, em menor grau, as associações de base -, cujas funções se encontram consolidadas e delimitadas por uma longa história, apresentam padrões mais nítidos e concentrados; as organizações civis "emergentes" ou comparativamente mais recentes, como as ONGs, distinguem-se por apresentar resultados discrepantes nas duas cidades. Assim, entidades assistenciais mexicanas ou paulistanas não invocaram sequer uma vez os argumentos eleitoral, de filiação ou de identidade, ao passo que apresentaram a maior concentração em um só argumento: serviços. Em ambos os contextos, as associações de base prescindiram do argumento de filiação e foram, junto com as entidades de coordenação, os atores que invocaram o argumento eleitoral. De sua parte, as entidades de coordenação respondem sozinhas pela quase totalidade dos argumentos de filiação citados, mas são as que recorrem, de modo mais equilibrado, a todos os argumentos. As ONGs apresentam a composição mais contrastante entre os dos contextos: no México, sustentam majoritariamente o argumento de identidade e, em São Paulo, os de intermediação e proximidade (nessa ordem).

A diversidade de argumentos invocados é relevante não apenas por evidenciar os custos cognitivos de posturas que optam por cancelar, já de saída, a problemática da representação no universo das organizações civis, como também, fun- 
damentalmente, por suas implicações para a accountability societal na inovação democrática. Existem mecanismos formais de autorização e, por conseguinte, de sanção e de controle interno no universo das organizações civis, embora os dois argumentos que explicitam a presença desses mecanismos como fonte de legitimidade-eleitoral e de filiação - sejam numericamente pouco expressivos quando se consideram os dois contextos urbanos em seu conjunto. Apesar de a ausência de autorização ser comum nos demais argumentos, neles se esgrimem reivindicações de legitimidade apoiadas na qualidade da representação exercida ou representatividade e na ausência de representação de determinados grupos sociais. Cumpre lembrar que é consenso, no campo das teorias da representação, o fato de a autorização não resolver a questão da representatividade (Pitkin, 1985 [1967]; Sartori, 1992; Manin; Prezeworki; Stokes, 1999a, 1999b); em realidade, as queixas sobre a falta de representatividade correm paralelas à construção das instituições do governo representativo.

$\mathrm{O}$ argumento de identidade se baseia na mesma lógica das concepções de representação, que na teoria e nos debates históricos da representação política tem recebido nomes, como representação sociológica, especular, descritiva, simbólica - standing for. Mais: noções de representação especular também animaram, outrora, parte do debate político pela introdução da representação proporcional e pela concepção das funções do parlamento. ${ }^{23}$ Sem dúvida, nessa perspectiva, quanto maior a coincidência esperada entre os atributos encarnados pelo representante e os interesses do representado, menor a urgência de mecanismos de controle e, em última instância, de autorização; por isso, não surpreende que reivindicações de

\footnotetext{
${ }^{23}$ Parte das primeiras defesas da representação proporcional nos primórdios da história do parlamento concebia a função dessa instituição política como uma reprodução, em escala, da composição social dos atributos sociodemográficos relevantes em uma sociedade dada; uma espécie de miniaturização da sociedade, graças à qual as decisões poderiam ser consideradas como iguais àquelas que os cidadãos prefeririam se houvesse condições físicas e materiais para se reunir e deliberar (Pitkin, 1985 [1967], 1989).
}

legitimidade e propostas de inovação política centradas na representação de atributos substantivos sejam polêmicas. Todavia, a explosão da política da diferença, a extensão de expedientes de representação proporcional para minorias sociodemográficas, assim como a incorporação à teoria democrática e, especificamente, às teorias da representação, das críticas da antropologia e do pensamento pós-moderno às categorias universais, mostram que, nas democracias contemporâneas, há espaço para afirmações de legitimidade ancoradas em posições sociais ou "perspectivas" (Young, 2002) de gênero, raça e minorias, quando essas posições sociais são reconhecidas como sistemática e indesejavelmente sub-representadas ou excluídas dos canais tradicionais de representação. Trata-se de uma legitimidade "metaprocedimental" que, claro está, não pode se sustentar inteiramente sem formas procedimentais, sejam elas de autorização ou de controle. A combinação de déficits de legitimidade procedimental com fontes posicionais de legitimidade socialmente reconhecida ajuda a entender não apenas a ambigüidade das organizações civis orientadas por lógicas identitárias com relação a seus beneficiários, mas também a do mundo das instituições políticas com relação a essas organizações e aos reclamos identitários de representação. ${ }^{24}$

A qualidade da representação e os mecanismos de controle também admitem conjugação em um só argumento, como é mostrado na afirmação da proximidade como fonte de legitimidade. A proximidade não figura como elemento-chave das concepções e debates históricos da representação e, sem dúvida, sua estirpe não é liberal. A convicção do valor da política de base, do trabalho lado a

${ }^{24}$ Um caso de destaque dessa ambigüidade ocorre com os conselheiros do Instituto Federal Eleitoral (IFE) no México, que são eleitos pelos partidos políticos na Câmara de Deputados, privilegiando uma característica definida como sendo de representação simbólica, a saber, seu caráter cidadão, entendido como não-partidário. Assim, e por mais que possa parecer paradoxal, os representantes do governo representativo elegem representantes cidadãos para exercerem uma modalidade altamente institucionalizada de representação presuntiva (nesse caso, imputada ou atribuída) em uma suposta relação de identidade com os cidadãos. Agradeço a Ernesto Isunza por me haver apresentado uma cuidadosa reflexão esse respeito. 
lado com o "povo”, foi característica da teologia da liberação na América Latina, com acentuada presença no Brasil, mas também é possível rastrear o valor da participação dentro da família das esquerdas. Apesar de seu fundo de crítica à separação entre representante e representado, que, em princípio, compromete a própria idéia da representação, o argumento acarreta a possibilidade de que se exerçam controles sobre o representante. Aqui não existe ambigüidade com respeito à relação das organizações civis com seus beneficiários, e sim à sua relutância em assumir plenamente a função de representantes, ou seja, o compromisso de não substituir os representados, e sim de ajudá-los a construir seu próprio protagonismo. Para além do mérito desse compromisso, não é possível avançar demasiado com o argumento em direção a escalas amplas de agregação de interesses, ainda que seu valor pareça inegável em micro-processos de exercício de controles locais sobre atores coletivos com funções de representação.

As críticas e o ceticismo mais agudos frente ao crescente protagonismo das organizações civis como agentes de intermediação política se mostram pertinentes com relação a boa parte das práticas de representação exercidas nas duas metrópoles aqui analisadas. A representação presuntiva justificada com o argumento de serviços, amplamente difundido, tem implicações perniciosas do ponto de vista da teoria democrática e se assemelha a velhos argumentos de legitimidade esgrimidos pelos regimes populistas na América Latina. Não existe accountability possível quando a concessão de benefícios se aproxima da dádiva, e o representante emerge como outorgante sem intermediações. Cumpre mencionar, para evitar mal-entendidos, que a filantropia e a beneficência desempenharam historicamente um papel relevante em sociedades desiguais - como o Brasil e o México -, mas as reservas se referem à projeção de suas características ao mundo da política, no qual cidadãos, por intermediação de outros, realizam funções de controle social sobre o poder público.

$\mathrm{O}$ argumento mais novo invoca a falta de representação de determinados grupos sociais, mas, como seria de se esperar, não possui mecanismos de controle nem delimitação clara sobre suas próprias fronteiras. Embora careça implícita ou explicitamente de mecanismos de controle pelos beneficiários, o argumento da intermediação não pressupõe sua anulação lógica como ocorre no caso anterior, dado que sua peculiaridade está baseada no reconhecimento do exercício de funções de intermediação explicitamente políticas perante o poder público e em nome de segmentos da população cuja voz é pouco escutada. Esse argumento mostra com nitidez a questão da accountability societal: por um lado, afirma o valor de uma representação especificamente política exercida por organizações civis, admitindo a distância entre representantes e representados, e a importância de ter acesso ao Estado; por outro, a incidência em políticas públicas e o controle societal efetuado por essas organizações sobre o poder público ocorrem de modo "solto" em relação aos eventuais beneficiários, seja pela inexistência de autorização ou pela precariedade ou franca ausência de mecanismos capazes de sustentar o controle social sobre sua atuação.

Em suma, a questão da accountability societal não pode ser ignorada, mas não aceita respostas fáceis nem conclusões peremptórias de condenação ou defesa da chamada sociedade civil. Dentro do universo das organizações civis, aquelas que exercem funções de controle societal sobre o poder público o fazem sob um manto de suspeição e, nesse sentido, o uso reiterado de mecanismos de controle social ou interno sobre as organizações pode eventualmente surgir como fonte alternativa de legitimidade, diante da ausência de expedientes de autorização. Aqui, como no caráter periódico ou em intervalos regulares das eleições (Manin, 1998), o tempo é a variável fundamental, pois a reiteração do controle por parte dos beneficiários implica alguma modalidade de anuência sobre a atividade do controlado.

Além do tempo, ou seja, dos efeitos de antecipação induzidos pela previsibilidade de eventuais sanções associadas ao exercício de controles cíclicos ou permanentes, os argumentos comuns 
encontrados na Cidade do México e em São Paulo sugerem que é imprescindível conjugar três requisitos. Primeiro, no exercício da representação presuntiva e, portanto, desprovida de autorização, o lócus da representação não pode ser omitido, ainda que as funções que nele se exercem possam permanecer subentendidas. Segundo, mesmo com níveis distintos de formalização e com resultados incertos, é preciso contar com dispositivos de aproximação simbólica e física entre organizações e beneficiários, dispositivos que, por sua vez, possam abrir caminho à eventual estabilização de mecanismos de controle e sanção. Terceiro, independentemente de que mecanismos sejam esses e de qual venha a ser sua eficácia, é imprescindível pressupor que sua ativação estará em condições de incidir, em algum grau, sobre a atuação do representante no lócus da representação. Trata-se de requisitos mínimos para tornar compatível a representação política exercida por organizações civis com princípios básicos da democracia, de modo que sua conjugação permita ou, ao menos, torne desejável, a projeção da atuação das organizações civis para o plano do exercício de controles societais sobre o poder público em contextos institucionais democráticos.

(Recebido para publicação em janeiro de 2008) (Aceito em março de 2008)

\section{REFERÊNCIAS}

ALNOOR, Ebrahim; EDWARD, Weisband (Coord.) Global accountabilities: participation, pluralism, and public ethics. Cambridge: Cambridge University Press, 2007.

ANSELL, Chris. The networked polity: regional development in Western Europe. Governance, London, v.13, n.3, july, 2000.

ATKINSON, Rowland; FLINT, John. Accessing hidden and hard-to-reach populations: snowball research strategies. Social Research Update, United Kingdom, University of Surry, n.33, 2003. Disponível em: www.soc.surrey.ac.uk/sru/ SRU33.html

CAIN, Bruce E., DALTON, Russel J.; SCARROW, Susan E. (Coord.) Democracy transformed? Expanding political opportunities in advanced industrial democracies: comparative politics. Oxford: Oxford University Press, 2003.
CAMPILONGO, Fernandes Celso. Representação política. São Paulo: Ática, 1988.

CASTIGLIONE, Dario; WARREN, Mark E Rethinking representation: seven theoretical issues. Prepared for delivery at the Midwest Political Science In: ASSOCIATION ANNUAL CONFERENCE, 40., Chicago, april, 2005.

CHALMERS, Douglas A.; VILAS, Carlos M. (Ed.) The new politcs of inequality in Latin America. Rethinking participation and representation. Oxford: Oxford University Press, 1997.

MARTIN, Scott B.; PIESTER, Kerianne. Associative Networks: new structures of representation for the popular sector?. In: ; VILAS, Carlos M. et al. The new politics of inequality in America. Rethinking participation and representation. Oxford: Oxford University Press, 1997.

CHANDHOKE, Neera. Governance and pluralisation of state, implications for democratic citizenship. Economic and Political Weekly, Munbai, v.38, n.28, 12th to 18th July 2003. p.2957-2968, 2003.

COHEN, Joshua; ROGERS, Joel. Associations and democracy. New York: Verso, 1995.

CORNWALL, Andrea; COELHO, Vera Schattan (Coord.) Spaces for change? The politics of Participation in New Democratic Arenas. London: Zed Books, 2007.

The politics of citizen participation in new democratic arenas. In: $\overline{\text { __ }}$ (Org.) Spaces for change? London: Zed Books, $2007 \mathrm{~b}$. v.1, p.1-29.

DAGNINO, Evelina. Sociedade civil, espaços públicos e a construção democrática no Brasil: Limites e Possibilidades. In: (Org.). Sociedade civil e espaço público no Brasil. São Paulo: Paz e Terra, 2002.

; OLVERA, Alberto; PANFICHI, Aldo. Para uma outra leitura da disputa pela construção democrática na América Latina. In: ; _ ; _ (Coord). A disputa pela construção democrática na América Latina. São Paulo: Paz e Terra; Campinas, SP: Unicamp, 2006.

DOBROWOLSKY, Alexandra; JENSON, Jean. Shifting patterns of representation: the politics of 'children', 'families' 'women. Haliffax: St. Mary's University, 2002.

FOX, Jonathan et al (Coord.) Derecho a saber. Balance y perspectivas. México: Fundar/ Woodrow Wilson Internacional Center, 2007.

FRIEDMAN, Elisabeth Jay; HOCHSTETLER, Kathryn. Assessing the third transition in Latin American democratization: representational regimes and civil society Argentina and Brazil. Comparative Politics, [S.l.], v.35, n.1, out., 2002,

FUNG, Archon; WRIGHT, Eric Olin.Thinking about empowered participatory governance. In:

(Ed) Deepening democracy: institucional innovation in empowered participatory governance. London: Verso, 2003.

GALVÃO, J.P. Sousa de. Da representação política. São Paulo: Saraiva, 1971.

GOODMAN, Leo. Snowball sampling. Annals of Mathematical Statistics, [S.l.], v.32, n.1, 1961.

GURZA LAVALLE, Adrián. Sem pena nem glória. O debate da sociedade civil nos anos 1990. Novos Estudos Cebrap, São Paulo, n.66, 2003a.

Cidadania, igualdade e diferença. Lua Nova, São Paulo, Cedec, n.59, 2003b.

HOUTZAGER, Peter; ACHARYA. Beyond comparative anecdotalism: lessons on civil society and participation from São Paulo, Brazil. World Development, [S.l.], v.33, n.6, p.951-964, 2005. 
; _ _ CASTELLO, Graziela. Democracia, pluralização da representação e sociedade civil. Lua Nova, São Paulo, n. 67, p.49-103, 2006a.

Representação política e organiza-

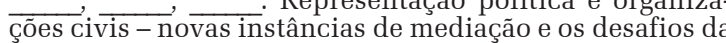
legitimidade. Revista Brasileira de Ciênncias Sociais, São Paulo, Anpocs, v.21, n. 60, 2006 b.

In whose name? Politica representation and civil organizations in Brazil. Working Paper 249, Brigthon, England, Institute of Developmen Studies, University of Sussex, 2005c.

CASTELLO, Graziela; BICHIR, Renata. Protago$\overline{\text { nistas }}$ na sociedade civil: redes e centralidades de organizações civis em São Paulo. Dados: revista de Ciências Sociais, São Paulo, v.50, n.3, 2007.

ISUNZA, Vera Ernesto. Participación, controles sociales y representación. Precisiones conceptuales para el debate contemporáneo sobre la innovación democráti ca”. In: ISUNZA, Vera Ernesto; GURZA LAVALLE, Adrian. Veredas de innovación democrática. Teoría y práctica de la representación, la participación y el control ciudadanos en América Latina. México: Editorial Porrúa. (Trabalho não publicado)

HELLER, Patrick. O perfil político e institucional da democracia participativa: lições de Kerala, India”. In: SANTOS, Boa Ventura (Ed). Democratizar a democracia: os caminhos da democracia particpativa. Rio de Janeiro: Civilização Brasileira, 2002. p.599-648

. Moving the state: the politics of democratic decentralization in Kerala, South Africa and Porto Alegre. Politcs e Society, [S.1.], v. 29, n.1, 2001.

HOUTZAGER, Meter; GURZA LAVALLE, Adrian. The paradox of civil society representation constructing new forms of democratic legitimacy in Brazil. In: TÖRNQUIST, Olle; WEBSTER, Neil; STOKKE, Kristian (Coord). Rethinking popular representation. London: Sage. (Trabaho não publicado).

ARCHARYA, Arnab. Who participates? Civil society and the new democratic politics in São Paulo, Brazil. Working Papers, Sussex, Intitute of Development Sudies, v.210, p.1-72, 2003.

ISUNZA, Vera Ernesto; OLVERA, Alberto (Coords.) Democratización y accountability y sociedad civil: participación ciudadana y control social. México: Porrua/ CIESAS Universidad Veracruzana/ Cámara de Diputados, 2006a.
; GURZA LAVALLE, Adrian. Veredas de innovación democrática Teoría y práctica de la representación, la participación y el control ciudadanos en América Latina. México: Editorial Porrúa. (Trabalho não publicado).

LANDIM, Leilah. Experiência militante: histórias das assim chamadas ONGs. In:_ (Org.) Ações em sociedade: militâncias, caridade, assistência, etc., Rio do Janeiro: Iser/NAU, 1998.

MANIN, Bernard. As metamorfoses do governo representativo. Revista Brasileira de Ciências Sociais, São Paulo, v.10, n,29, out., 1995.

. The principles of representative government Cambridge: Cambridge University Press, 1998.

- PRZEWORSKI, Adam; STOKES Susan. Eleicões e representação. In: PRZEWORSKI, Stokes; MANIN, Bernard. (Ed.). Accountability and representation. Cambridge: Cambridge University Press, 1999a.

; STOKES, Susan Introduction. In: PRZEWORSKI, Stokes, MANIN, Bernard. (Ed.). Accountability and representation. Cambridge: Cambridge University Press, 1999b.

MARQUES, Eduardo Cesar. Redes sociais e poder no Es- tado brasileiro: aprendizados a partir de políticas urbanas. Revista Brasileira de Ciências Sociais, São Paulo, v.21, n.60, p.15-41, 2006.

PERUZZOTTI, Enrique. Civil society, representation and accountability: restating current debates on the representativeness and accountability of civic associations. In: JORDAN, Lisa; VAN TUIJL, Peter (Coord.), NGO Accountability. Politics, principles and innovations. Londres: Earthscan, 2007.

PITKIN, Hanna. The concept of representation. Berkley: University of California Press. 1967.

Representation. In: BALL, Terrence; FARE, James; HANSEN, Russell L. (Ed.) Political innovation and conceptual change. Cambridge: Cambridge University Press, 1989.

PRZEWORSKI, Adam. Accountability social en América Latina y más allá. In: PERUZZOTTI, Enrique; SMULOVITZ, Catalina. Controlando la política: ciudadanos y medios den las nuevas democracias latinoamericanas. Buenos Aires: Temas, 2002.

ROBERTS, Kenneth M. Party-society linkages and democratic representation in Latin America. Canadian Journal of Latin American and Caribbean Studies, Montreal, v.27, n.53, 2002.

SÀNCHEZ-MEJORADA, Fernández Cristina; ÁLVAREZ, Enríquez Lucia. La política gubernamental en materia de participación ciudadana en el gobierno del Distrito Federal. In:_et al (Coord.), ¿Una ciudad para todos? La Ciudad de México, la experiencia del primer gobierno electo. México: UAM/Conaculta/Inah, 2002.

SANTOS, Boaventura Souza de. Democratizar a democracia: os caminhos da democracia participativa. Rio de Janeiro: Civilização Brasileira, 2002.

SARTORI, Giovanni. A teoria da representação no Estado representativo moderno. Revista Brasileira de Estudos Políticos, Belo Horizonte, UFMG, n.22, 1962.

SUDMAN, S.; KALTON, G. New developments in the sampling of special populations. Annual Review of Sociology, [S.l.], n.12, p.401-29, 1986.

TATAGIBA, Luciana. Os conselhos gestores e a democratização das políticas públicas no Brasil. In: DAGNINO, Evelina. Sociedade civil e espaços públicos no Brasil., São Paulo: Paz e Terra, 2002.

TÖRNQUIST, Olle; WEBSTER, Neil; STOKKE, Kristian (Coord.) Rethinking democratic-popular representation. London: Sage. (Trabalho não publicado).

URBINATI, Nadia. Representation as advocacy: a study of democratic deliberation. Political Theory, [S.1.], v.28, n.6, p.758-786, 2000.

; WARREN, Mark E. The concept of representation in contemporay democrátic theory. New York: Draft, 2007. WARREN, Mark E. Democracy and association. Princeton; Oxford: Princeton University Press, 2001.

YOUNG, Iris Marion. Inclusion and democracy. Oxford: Oxford University Press, 2002. 


\section{SOCIEDADE CIVIL, REPRESENTAÇÃO E A DUPLA FACE DA ACCOUNTABILITY: cidade do México e São Paulo}

\section{Adrian Gurza Lavalle} Graziela Castello

Organizações civis desempenham, de modo crescente, funções de representação política. A análise das condições de legitimidade das novas práticas de representação é crucial para a inova-
ção e teoria democráticas. A partir da ção e teoria democráticas. A partir da accountability, assumida como compoquisa, este artigo (i) examina research strategy, this paper (i) examiempiricamente (com base em resulta- nes empirically (based in surveys dhe existing representation ções civis que assumem funções de re- that assume representative functions presentação na Cidade do México e em in Mexico City and in São Paulo, and São Paulo, e (ii) avalia seus mecanismos internos de accountability e suas funções de controle sobre o poder público do ponto de vista da teoria democrática.

mechanisms of accountability and their

PALAVRAS-CHAVE: Sociedade civil, representação, accountability, legitimidade. med as a sine qua non component

control functions on public government

from the point of view of the democratic theory.

CIVIL SOCIETY, REPRESENTATION AND México city and São Paulo

Adrian Gurza Lavalle

Civil organizations carry out, increasingly, functions of political conditions of legitimacy of the new epresentation practices is crucial for the KEYWORDS: civil society, representation, accountability, legitimacy.

\section{LA SOCIÉTÉ CIVILE, LA REPRÉSENTATION ET LES DEUX CÔTÉS DE \\ L'ACCOUNTABILITY: México et São Paulo}

\author{
Adrian Gurza Lavalle \\ Graziela Castello
}

Les organisations civiles développent de plus en plus des fonctions de représentation politique. L'analyse des conditions de légitimité des nouvelles pratiques de représentation est devenue cruciale autantt pour l'innovation que pour la théorie démocratiques. En partant du principe que l'accountability est un élément sine qua non de la représentation démocratique et une stratégie de recherche, : (i) on analyse, dans cet article, de manière empirique (sur les bases des résultats des surveys), les notions de représentation qui existent au sein des organisations civiles assumant des fonctions de représentation à Mexico et à Sao Paulo et (ii) on évalue leurs mécanismes internes d'accountability ainsi que leur contrôle sur les pouvoirs publics, du point de vue de la théorie démocratique. MoTS-CLÉs: société civile, représentation, accountability, légitimité. 